\title{
Land use and cropping patten analysis of Kerala agroecosystem and food insecurity.
}

\author{
Bharath Chandran $\mathrm{C}^{* *}$ \\ * TERI School of Advanced Studies New Delhi \\ DOI: 10.29322/IJSRP.11.12.2021.p12005 \\ http://dx.doi.org/10.29322/IJSRP.11.12.2021.p12005
}

\begin{abstract}
Kerala is not the first place to look when searching for food insecurity in India, but the dependency on other states for meeting its demand will paint a different picture. Along with declining production of major food crops, conversion of fallows and wetlands to non-agricultural purposes leads to fragmentation and pressure on already declining agricultural land area. The study is an extension of previous studies carried regarding the same topic, but there is a research gap after 2012. Hence the study is to include secondary data available to calculate agricultural growth in the state using Cuddy Della Valle instability index and CAGR (Compound Annual growth Rate). Crop diversification was also calculated to measure the extent of diversification within the state which shows a higher level of diversification at crop level. There has been an overall decrease in area and production for most of the food crops whereas the values remain constant for non-food crops, along with the decline there is a significant decline in areas related to agricultural production such as fallow and grazing lands.
\end{abstract}

Index Terms- Land use change, Crop diversification, Instability index, Herfindahl Index, Food crops, Nonfood crops, food security

\section{INTRODUCTION}

$\mathrm{K}$ erala has been the frontrunner in the Human development index and other social performance indicators within the country and this is reflected in its top position in the SDG index. Even though there are no immediate concerns regarding food insecurity within the region the pandemic has provided as the glimpse of how situations can change around especially for a state which is a consumer rather than a producer. There is a gradual decline in total cropped area and this loss is decline is more significant in terms of food crops. With states trying to attain self-sufficiency within the regions, the rising population and demand in food is not matching up with inhouse production and productivity. According to FAO food security consists of four dimensions including availability, accessibility utilization and stability. The last dimension of stability is a long-term factor and sustainable production is the major criteria here.
The deficit gap between production and consumption was around $75 \%$ around 1980 s which and presently around $85 \%$. If not addressed properly according to the Agricultural development policy of the state, the state could be the most food insecure place. A small price fluctuation in the price can have bigger impacts for the consumers as the supply chain is long and complicated. With more agricultural land converted to non-agricultural use, fallows and permanent pastures are becoming nonexistent in the state.

Along with the food production systems another part is the loss of Agro biodiversity within the nonexistent tropical ecosystem. From below sea level to dry land rice Kerala is home to unique Agro ecosystems which are the last islands of biodiversity hotspots. Along with loss of species the conversion of paddy fields which acts as the hydrological buffers in the region is also under threat from conversion and pollution. This conversion has to be read along with the recent floods in the state and how fragile the hydrology and ecology is in the state. The analysis is to understand the degree of change and how agricultural composition is changing in the state.

\section{LITERATURE REVIEW}

Literature Review

Food security

FAO defines food security as "a situation in which the people physical, social and economic access to sufficient, safe and nutritious food that meets their dietary needs and food preferences for an active and healthy life"' (World Food Summit 1996). Newer definitions focus on Accessibility, availability, utilization and stability over space and time. The recent pandemic and climate extremes have impacted the food systems and the cost of healthy diets across the globe. The drivers identified include unaffordability of healthy diets, economic slowdowns and climate variabilities. (FAO, 2021). SDG index is the matrix used in determining the performers and front runners in the country. The 2020-21 NITI Aayog report puts Kerala in Front runner for the SDGs directly related to food security. These SDGs include SDG1(no poverty), SDG2 (Zero hunger), SDG3 (Good health and wellbeing). The percentage population covered under the National Food Security Act is $100 \%$ (Aayog, 2021). Kerala is a food deficit state which is heavily dependent on surplus neighboring states for its population demand which is catered by FCI (K P ANOOP, 2018). 
The food security concept of availability focuses on how much food is available for consumption, which is an external factor for Kerala as it is depending on other states. Hence the fourth pillar of food security which is stability over a long time is the key area of concern. How Kerala can sustain its increasing demand without increasing own production. Coming to own production studies had shown the declining trend in the state for food crops.

Table 1 Percentage change in Cropped Area for selected crops (Source: Data Book on Agriculture, 2000, State Planning Board \& Agricultural Statistics, Department of Economics and Statistics, Govt. of Kerala.)

\begin{tabular}{|l|l|l|}
\hline $\begin{array}{l}\text { Percentage change } \\
\text { (in \%) }\end{array}$ & $\begin{array}{l}1952-53 \text { to } \\
1985-86\end{array}$ & $\begin{array}{l}1990-91 \text { to } \\
2000-01\end{array}$ \\
\cline { 1 - 2 } Crops & -8.6 & -37.48 \\
\hline Rice & -2.59 & -53.03 \\
\hline Pulses & 63.73 & 6.32 \\
\hline Coconut & -0.89 & -23.60 \\
\hline Tapioca & 38.62 & 76.69 \\
\hline Banana & 427.80 & 23.15 \\
\hline Rubber & 54.31 & 17.74 \\
\hline Pepper & &
\end{tabular}

Table 1 from the agricultural statistics of Kerala shows that there is been a decline in cropped area for major food crops especially from 2000 onwards except for banana and rubber. Along with the area for cultivation net production is declining for the major staple crop rice in the state, which have food security implications (Rejula K, 2015). The state has a per capita grain production of less than $100 \mathrm{~kg}$, which even though do not suggest any signs of food insecurity. It's the purchasing power which impacts the food access and availability in Kerala, so any disturbances in the food distribution can have negative impact of Food security for the state (BMK Raju, 2016).

Studies had showed how diversified agricultural system can improve income along with the household consumption. These interventions include intercropping, household level processing, livestock rearing and focusing of home gardens especially in the context of Kerala (Santhakumari Kalavathi, 2010).

Agricultural area in the state has been under stagnation or even declining leading to a rapid land use change in the state followed by urbanization. This rapid land use change is witnessed across the state and can lead to increased Evapo-transpiration which is driven by economic interests. This can impact the water percolation, run off and base flow which are crucial variable especially for a state with high rainfall (N. Sajikumar, 2014).

The covid pandemic had made the already complex food systems more vulnerable to external shocks and Kerala too faced the consequences. The impact was visible in agricultural allied sector with impacts like decreased agricultural production, reduced prices, shortage of labor to name a few. The government interventions were necessary in these times for aiding the sector and providing recovery boost to the economy (PK Muthukumar, 2021).
It is in these settings, to identify how the production system is performing and to analyze it is of significance. This study is aimed at to create a picture of the system and its temporal variations and can it sustain future demands for a state aiming for self-sufficiency

\section{LITERATURE REVIEW}

This study is an extension of previous similar studies with updated recent data (till 2019). The 1952 study tfea Kerala has a large gap betweent the agricultural production and demand. The production and area for major food crops and declining and this could contribute to future food security concerns for a state who is trying to achiowe sustainability in thezsane field. Data analysis was conducted for the time period of 2004 to 2019 , using area and production for major food and non-food crops. The seconda7y data for the study85a\$\$50btained from the Department of Economics and -66.01 Statisties Kerala (http:///نww.ecostat.kerala.gov.in/index.php)

Thre5. 7 rain values have been. 6 sed to visualize the variation of agriqg!tyral and land use scemanis in the state. They are CAGR (Compound Annual Growth Rate), Cuddy Della value index and Crop diversification index. 7.50

Cuddy Della Valle index was used to estimate the instability index in area, production and productivity of the major crops. The main advantage of using a Cuddy Della Valle index is the alternate method of simple coefficient of variation overestimates the level of instability in time series data. The Cuddy Della Valle corrects this variation in our data.

$$
\text { Instability Index }=C V \sqrt{1}-R \text { sqaured }
$$

Where CV = Coefficient of variation in Percent

$\mathrm{R}$ squared $=$ coefficient of determination in a time series regression adjusted to degrees of freedom.

Crop diversification Index used to calculate the level of diversification in the state, via Herfindahl index (HI) method.

Here

$$
H I=\sum_{1}^{n} P i^{2}
$$

$\mathrm{Pi}=$ Acreage proportion of $\mathrm{i}^{\text {th crop }}$ in total cropped area

$\mathrm{n}=$ total crops

HI ranges from zero to one where zero represents a nearly perfect diversification, when monoculture is practiced the value approaches one. Diversification index is calculated by subtracting HI from one.

$\mathrm{DI}=1-\mathrm{HI}$

\section{Results and Discussion}

The results from the study are discussed below. The overall land use pattern was studied, most of the area related to agriculture from pastures to fallows are showing a declining trend over the same period. The reduction in pasture, grazing land and fallows 
can be grouped together as the common property resources which are declining and needs to be looked at the ground level. Land use categories such as Permanent pastures, fallow land is showing a high instability index value whereas the nonfood crop s shows the least value showing its stable production and area under cultivation

Table 2 Land use pattern growth rate and Instability index for Kerala from 2004-2019

\begin{tabular}{|l|l|l|l|}
\hline $\begin{array}{l}\mathrm{S} \\
\mathrm{N} \\
\mathrm{o}\end{array}$ & Land use pattern & $\begin{array}{l}\text { Instability } \\
\text { Index\% }\end{array}$ & $\begin{array}{l}\text { CAGR } \\
(\%)\end{array}$ \\
\hline 1 & $\begin{array}{l}\text { Land put to nonagricultural } \\
\text { use }\end{array}$ & 4.893394 & 0.36 \\
\hline 2 & Barren \& uncultivable land & 5.957913 & -6.66 \\
\hline 3 & $\begin{array}{l}\text { Permanent pastures and } \\
\text { other grazing land }\end{array}$ & 27.4963 & -23.75 \\
\hline 4 & Land under misc. tree crops & 24.28055 & -9.95 \\
\hline 5 & Cultivable waste & 7.610142 & 2.15 \\
\hline 6 & $\begin{array}{l}\text { Fallow other than current } \\
\text { fallow }\end{array}$ & 8.765833 & 0.72 \\
\hline 7 & Current Fallow & 26.00938 & -1.32 \\
\hline 8 & $\begin{array}{l}\text { Total Cropped Area } \\
9\end{array}$ & $\begin{array}{l}\text { Food Crops } \\
\text { Non-Food Crops }\end{array}$ & -1.02 \\
\hline 0 & 5.436934 & -2.32 \\
\hline
\end{tabular}

Table 2 shows how each land use category is performing in respect to the growth rate and Instability index. Two categories showing and overall increase in CAGR are land put to non-agricultural land use and cultivable waste. These two categories do not contribute to agricultural production rather a sign of declining production.

\section{Growth and Instability index for major crops}

12 Major crops were used for the study and these food and nonfood crops contribute the majority of the area and production in the state and plays more important role in food security and local economy.

Instability index and CAGR was calculated for the area under the crop, production and productivity. Most of the crops in the list showed a negative growth rate in terms of area. This was similar for production and productivity apart from Cardamom, tea and coffee. The overall trend in the case of productivity is more or less stagnating with no improvement or decline.

Three crops pepper, cashew and ginger are showing a heavy annual rate of decline in area and production as depicted in figure 1.

Table 3 Crop growth rate and instability index for Major crops in Kerala from 2004-2019

\begin{tabular}{|l|l|l|l|l|}
\hline & \multicolumn{2}{|l|}{ Area } & \multicolumn{2}{l}{ Production } \\
\hline & \multicolumn{2}{|l|}{ Instability Index } & CAGR & Instability Index \\
\hline Rice & 6.61 & -2.35 & 7.54 \\
\hline Tapioca & 4.86 & -2.36 & 5.69 \\
\hline Banana & 5.5 & -0.71 & 8.43 \\
\hline Coconut & 3.366 & -1.11 & 4.81 \\
\hline Rubber & 1.43 & 0.92 & 12.23 \\
\hline Pepper & 18.26 & -6.79 & 24.3 \\
\hline Cashew & 11.45 & -4.83 & 13.26 \\
\hline Arecanut & 2.57 & -0.77 & 8.35 \\
\hline Cardamom & 12.99 & 4.69 & 22.28 \\
\hline Tea & 7.31 & 0.27 & 4.78 \\
\hline Coffee & 0.32 & 6.55 & \\
\hline & & & \\
\hline & & & \\
\hline
\end{tabular}

When we look at the instability index for area pepper, cashew and cardamom is showing a higher instability. Whereas for the plantation crop rubber this holds true for instability in production and productivity. All the major food crops are showing a negative growth rate whereas the growth is only seen for plantation and spice crops. 


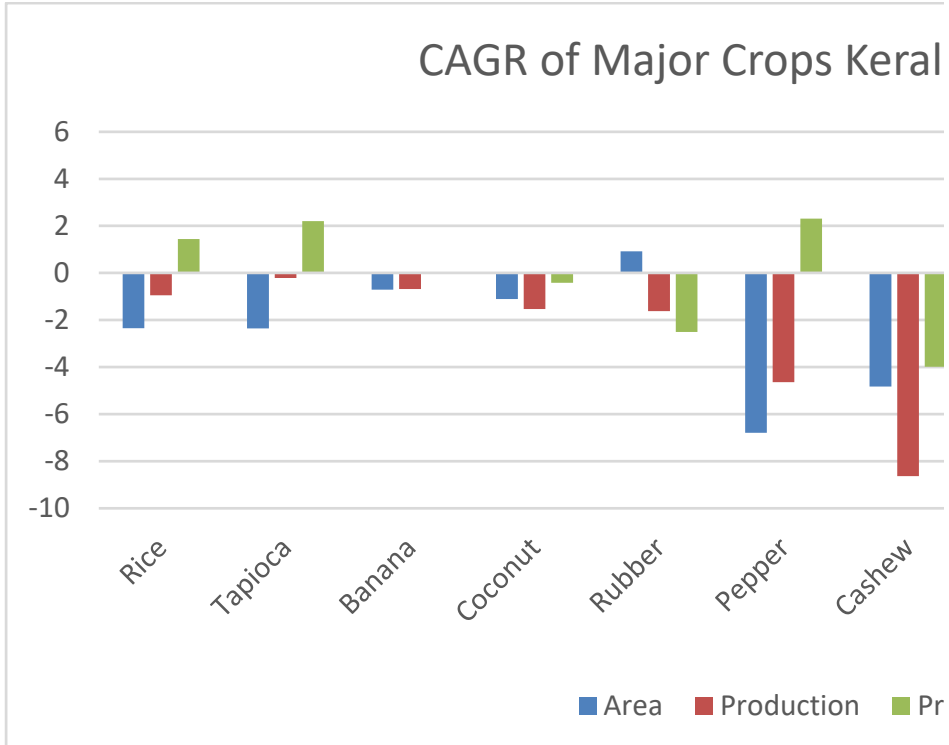

Figure 1 CAGR of major crops from 2004 - 2019

Table 4 Proportion of Major Food Crops in Kerala

\begin{tabular}{|c|c|c|c|}
\hline & Rice & Tapioca & Banana \\
\hline 2004-05 & $9.68 \%$ & $2.95 \%$ & $1.96 \%$ \\
\hline $2005-06$ & $9.24 \%$ & $3.03 \%$ & $2.06 \%$ \\
\hline $2006-07$ & $9.03 \%$ & $2.99 \%$ & $2.03 \%$ \\
\hline $2007-08$ & $8.29 \%$ & $3.04 \%$ & $2.15 \%$ \\
\hline 2008-09 & $8.69 \%$ & $3.24 \%$ & $2.03 \%$ \\
\hline $2009-10$ & $8.77 \%$ & $2.81 \%$ & $1.92 \%$ \\
\hline $2010-11$ & $8.05 \%$ & $2.73 \%$ & $2.22 \%$ \\
\hline 2011-12 & $7.82 \%$ & $2.80 \%$ & $2.22 \%$ \\
\hline $2012-13$ & $7.61 \%$ & $2.68 \%$ & $2.35 \%$ \\
\hline $2013-14$ & $7.63 \%$ & $2.58 \%$ & $2.38 \%$ \\
\hline 2014-15 & $7.55 \%$ & $2.88 \%$ & $2.36 \%$ \\
\hline $2015-16$ & $7.49 \%$ & $2.64 \%$ & $2.28 \%$ \\
\hline $2016-17$ & $6.63 \%$ & $2.66 \%$ & $2.21 \%$ \\
\hline $2017-18$ & $7.53 \%$ & $2.72 \%$ & $2.41 \%$ \\
\hline 2018-19 & $7.89 \%$ & $2.41 \%$ & $2.06 \%$ \\
\hline
\end{tabular}

Table 4 shows the area under major food crops in the state, the share under rice is declining throughout the period uniformly. Whereas tapioca and banana show slight fluctuation but overall, there is a drop.

Table 5 Proportion of Major Non-Food crops in Kerala

\begin{tabular}{|c|c|c|c|c|c|}
\hline & Coconut & Rubber & Pepper & Cashew & Arecanut \\
\hline 2004-05 & $30.01 \%$ & $16.04 \%$ & $7.93 \%$ & $2.72 \%$ & $3.59 \%$ \\
\hline $2005-06$ & $30.07 \%$ & $16.56 \%$ & $7.97 \%$ & $2.62 \%$ & $3.64 \%$ \\
\hline 2006-07 & $29.92 \%$ & $17.21 \%$ & $7.43 \%$ & $2.42 \%$ & $3.50 \%$ \\
\hline 2007-08 & $29.66 \%$ & $18.55 \%$ & $6.36 \%$ & $2.11 \%$ & $3.61 \%$ \\
\hline 2008-09 & $29.23 \%$ & $19.20 \%$ & $5.70 \%$ & $1.97 \%$ & $3.62 \%$ \\
\hline $2009-10$ & $29.18 \%$ & $19.69 \%$ & $6.43 \%$ & $1.84 \%$ & $3.72 \%$ \\
\hline $2010-11$ & $29.10 \%$ & $20.18 \%$ & $6.50 \%$ & $1.66 \%$ & $3.77 \%$ \\
\hline 2011-12 & $30.84 \%$ & $20.27 \%$ & $3.21 \%$ & $2.03 \%$ & $3.93 \%$ \\
\hline $2012-13$ & $30.80 \%$ & $20.82 \%$ & $3.27 \%$ & $2.01 \%$ & $3.93 \%$ \\
\hline 2013-14 & $30.90 \%$ & $20.95 \%$ & $3.21 \%$ & $1.88 \%$ & $3.82 \%$ \\
\hline 2014-15 & $30.25 \%$ & $20.95 \%$ & $3.25 \%$ & $1.73 \%$ & $3.68 \%$ \\
\hline $2015-16$ & $30.07 \%$ & $20.96 \%$ & $3.27 \%$ & $1.64 \%$ & $3.77 \%$ \\
\hline $2016-17$ & $30.24 \%$ & $21.33 \%$ & $3.30 \%$ & $1.61 \%$ & $3.78 \%$ \\
\hline 2017-18 & $29.48 \%$ & $21.36 \%$ & $3.30 \%$ & $1.54 \%$ & $3.67 \%$ \\
\hline 2018-19 & $29.60 \%$ & $21.43 \%$ & $3.22 \%$ & $1.51 \%$ & $3.72 \%$ \\
\hline
\end{tabular}

Coconut and rubber occupy the lions share in area under cultivation for non-food crops and the share has been remain constant with rubber plantations showing an increase in proportion. There has been a decline in proportion for pepper throughout this period. These numbers do not indicate the quantity but an overall figure of how crops are performing between each other. 
Trend in Cropped area along with share and Non Food crops
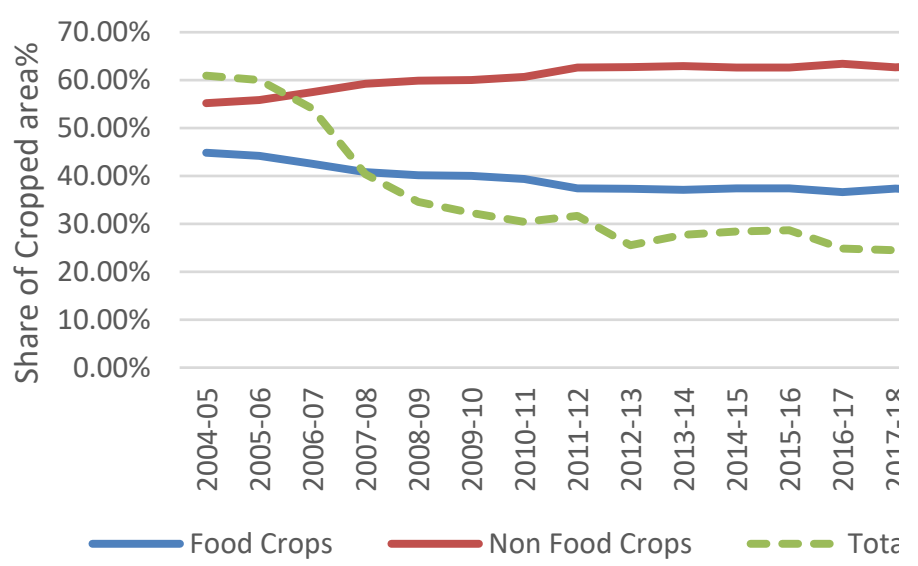

Figure 2 Total Cropped area Food crops vs Nonfood cropscropped Area 2004-2019

Overall, the cropped has declined throughout the last decade and this drop has mode impact for food crops with their share dropping gradually.

\section{Crop Diversification Index}

Diversified crop system enables better production and stability for the producers and for the food system. Crop diversification index was measured using Simpson diversity index method. A value of 1 refers to complete diversification, whereas when the value approaches to zero it reflects an agricultural production system depending on few crops. After a decline in the diversity index during the period 2008 to 2010, there has been a rise in diversification.

\section{Simpson Diversity Index (SDI)}

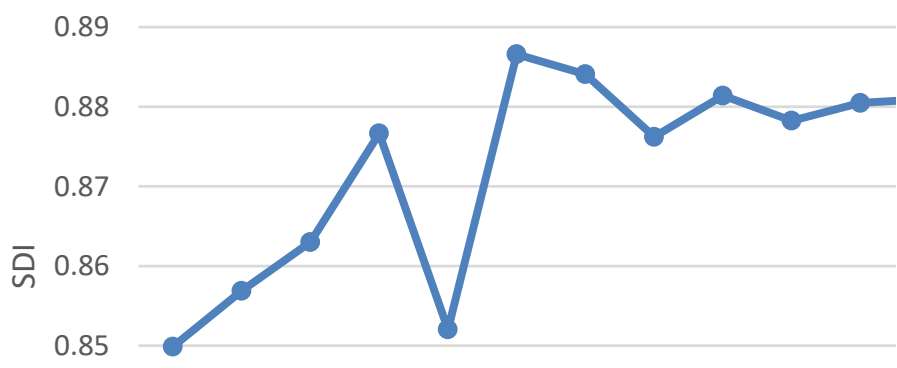

0.84

0.83

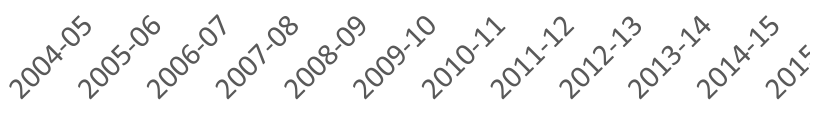

Figure 3 Simpson Diversity index for Kerala (2004-2019)

This publication is licensed under Creative Commons Attribution CC BY.

http://dx.doi.org/10.29322/IJSRP.11.12.2021.p12005

\begin{tabular}{|l|l|l|l|l|}
\hline & $2009-10$ & $2014-15$ & $2018-19$ & Average \\
\hline Kozhikode & 0.627039 & 0.609427 & 0.622549 & 0.619672 \\
\hline Kottayam & 0.669385 & 0.653029 & 0.675533 & 0.665982 \\
\hline Pathanamthitta & 0.732347 & 0.726017 & 0.731077 & 0.729814 \\
\hline Thiruvananthapuram & 0.731643 & 0.74452 & 0.747957 & 0.741373 \\
\hline Thrissur & 0.754553 & 0.739413 & 0.740887 & 0.744951 \\
\hline Alappuzha & 0.748305 & 0.764126 & 0.756956 & 0.756462 \\
\hline Kasaragod & 0.775248 & 0.753259 & 0.754854 & 0.76112 \\
\hline Malappuram & 0.760252 & 0.770773 & 0.758936 & 0.76332 \\
\hline Kannur & 0.804538 & 0.784962 & 0.789405 & 0.792968 \\
\hline Ernakulam & 0.810927 & 0.792066 & 0.793222 & 0.798738 \\
\hline Wayanad & 0.823644 & 0.815964 & 0.808854 & 0.816154 \\
\hline Kollam & 0.931107 & 0.800511 & 0.808102 & 0.846574 \\
\hline Palakkad & 0.841547 & 0.856719 & 0.848515 & 0.848927 \\
\hline Idukki & 0.868277 & 0.906037 & 0.903646 & 0.892653 \\
\hline
\end{tabular}

Figure 4 District level diversification from 2009-2019

Even though the state level diversification value tends to be on the higher sider, a detailed state level diversification value shows a different pattern. Using the result from figure 4 the districts can be grouped according to their level of diversification.

Districts with lower CDI: Kozhikode, Kottayam

Districts with medium CDI: Thiruvanathapuram, Thrissur, Alappuzha, Kasaragod, and Malappuram

Districts with higher CDI: Kannur, Ernakulam, Wayanad, Kollam, Palakkad, Idukki

\section{CONCLUSION}

The study was aimed for creating a broader picture of the production system within the state of Kerala and how its agricultural landscape has changed over the period. Most of the 
major food crops are showing a declined production and area throughout the period, which increases the states position for aiming for a food security. With a declined production the demand supply gap has to be addressed using production from neighboring states and central quotas.

Compared to food crops non-food crops has performed better, this could be attributed to the difference in marketing systems and the cost of cultivation. One major crop facing the risk is paddy and rice being the staple crop and its demand will only keep rising creates more pressure. Assuming a population growth rate of $10 \%$ by the year 2026 is nearly 1 million tonnes, whereas the demand supply gap is at a deficit of more than $80 \%$ (Karunakaran, 2014).

Paddy ecosystems and agricultural fallow lands play a bigger role in the water management and local biodiversity along with the food security dimension. With paddy land, pastures, grazing land and fallow land declining and getting fragmented the challenge is to address the growing demand and production gap sustainably.

Another observation is the contrasting performance for nonfood crops and food crops with the former showing stability in production and productivity. This market preference of cropping system from a food security point is alarming. With more area getting converted for non-agricultural purpose or non-food crops the production cost increases creating a negative feedback loop.

\section{LIMITATIONS}

The study could only focus from a production side as the demand side has not been taken into account, this means to paint a picture of food insecurity in the state is impossible. A detailed demand gap analysis should be taken accounting for imports from other states and in house production. A state wide result only touch the surface for broader picture of food security, as visualized in the district level crop diversification.

District level variations has not been accounted and with diverse
Agro ecological conditions the variation has wide range of impacts.

References

BMK Raju, C. R. (2016). Current Trends in Food Grains Production and Food Security. In R. N. K Sreedevi Shankar, Reshaping Agriculture and Nutrition Linkages for Food and Nutrition Security (p. 92). Hyderabad: ICAR - Central Research Institute for Dryland Agriculture.

Karunakaran, N. (2014). Paddy Cultivation in Kerala -Trends Determinants and Effects on Food Security. ARTHA JOURNAL OF SOCIAL SCIENCES, 21-35.

N. Sajikumar, R. R. (2014). Impact of land cover and land use change on runoff characteristics. Journal of Environmental Management, 1-9.

PK Muthukumar, S. R. (2021). Impact of COVID 19 on production and productivity of Kerala agriculture sector. International Journal of Innovative Science, Engineering \& Technology, 155-162.

Rejula K, S. R. (2015). An analysis of changing land use pattern and cropping pattern in a scenario of increasing food insecurity in Kerala state. Economic Affairs, 123-129.

Santhakumari Kalavathi, V. P. (2010). Improving food and nutritional security of small and marginal coconut growers through diversification of crops and enterprises. Journal of Agriculture and Rural Development in the Tropics and Subtropics, 101-109.

\section{AUTHORS}

First Author -Bharath Chandran C, Masters in Environmental Studies and resource management, TERI School of advanced studies and bharathchandrannair@outlook.com

Correspondence Author - Bharath Chandran C, Masters in Environmental Studies and resource management, TERI School of advanced studies and bharathchandrannair@outlook.com, Contact : +91 7012404281 